observed in the DK 2, DK 27 and DK 30 lines. DK 34 and DK 39 showed high genotypic effects, environmental plasticity and stability by high grain weight per spike and 1000-grain weight. The lines with high plasticity are recommended for breeding of intensive cultivars with positive response to improved growing conditions, whereas stable lines - as sources for more rigorous conditions.

Conclusions. Crossing of synthetics with genome $A B D$ with spring bread wheat allows improving wheat by its genotypic effect, plasticity and stability of the yield and its main components grain weight per spike and 1000-grain weight.

Key words: wheat, plasticity, stability, yield, grain weight per spike 1000-grain weight.

UDC:633.14:631.563

\title{
EFFECTS OF DIFFERENT STORAGE REGIMENS ON THE RYE SEED GERMINATION AND ABSCISIC ACID CONTENT
}

Zadorozhna $^{1}$ O.A., Yehorov ${ }^{1}$ D.K., Zhmurko ${ }^{2}$ V.V.

${ }^{1}$ Plant Production Institute n.a. V.Ya. Yuriev, Ukraine

${ }^{2}$ V.N. Karazin National University, Kharkiv, Ukraine

Long-term storage of rye (Secale cereale L.) seeds often causes certain difficulties. Previously, common recommendations for rye seed storage modes were specified. The longevity of rye seeds with 5-7\% of moisture content was studied after storage at unregulated temperature under the eastern forest-steppe conditions in Ukraine, $4^{\circ} \mathrm{C}$ and $-20^{\circ} \mathrm{C}$. The rye seed longevity under these conditions is discussed. A possibility of seed longevity predicting from data on accelerated aging and abscisic acid (ABA) content was investigated. The value of ABA content for seed longevity predicting and ABA activity at different storage modes are discussed.

Key words: rye seeds, storage, water content, longevity, abscisic acid

Introduction. Rye (Secale cereale L.) seeds belong to microbiotics, according to the Evart classification, i.e. to crops that lose their seed viability under natural storage conditions for three years [1]. Water content in seeds should not exceed 14\% for industrial storage [2]. There are special GenBank standards for long-term seed storage [3]: relative humidity of $15 \% \pm 3 \%$ and temperature of $-18 \pm 3^{\circ} \mathrm{C}$ in special depositories. These conditions are recommended for longterm orthodox seed storage. There were some preceded investigations which were directed at determination of optimal storage regimens for different crop seeds.

Review of published data and statement of research objectives. The results on the storage rye seeds with $5.5 \%$ of moisture content at $-15{ }^{\circ} \mathrm{C}$ and $10{ }^{\circ} \mathrm{C}$ are known. They indicate that after 26-year storage the higher seed germinability and the better parameters of seedlings (length and dry weight) were recorded for accessions stored at $-15^{\circ} \mathrm{C}$ than at $10{ }^{\circ} \mathrm{C}$ or at $0{ }^{\circ} \mathrm{C}$ [4]. Long-term seed storage is recommended at $-20^{\circ} \mathrm{C}$, with $5 \pm 1 \%$ of seed moisture; middleterm storage - at $10^{\circ} \mathrm{C}[5]$.

The lowest recommended level of seed moisture, which extends the seed longevity, ranges $2 \%$ to $6 \%$ for different crops. Further reduction in seed moisture is either not significant or does not prolong the seed longevity [6].

Monitoring of rye accessions with moisture content of 5-8\% stored for a long time at $4{ }^{\circ} \mathrm{C}$ for the seed germinability showed that in most cases the germinability did not change

(c) O.A. Zadorozhna, D.K. Yehorov, V.V. Zhmurko. 2020.

ISSN 1026-9959. Селекція і насінництво. 2020. Випуск 117. 
significantly for seeds with 6-7\% of moisture content [7]. Investigations are carried out to optimize the seed drying procedure and, thus, to prolong the seed longevity [8].

Different accelerated aging methods are used to simulate seed aging. High temperature and seed moisture content regimens are often used for seed accelerated aging [9]. The optimum moisture content was determined as 3-4\% for storage at $65{ }^{\circ} \mathrm{C}$ and $40-50{ }^{\circ} \mathrm{C}$ [10]. In a such experiment, where rye seeds had moisture content of $5 \%, 6 \% 7 \%$ and were stored at $37{ }^{\circ} \mathrm{C}$ for up to 24 months, no differences were observed between the seed germinability at these moisture levels in most cases. In some cases, a higher germinability was recorded for accessions with moisture content of $5 \%$ [11]. The seed longevity of different crops under accelerated aging conditions depends on seed moisture [12].

Phytohormones ratios play important roles in seed germination. The key role of abscisic acid (ABA) content in seed dormancy maintaining and germination starting is known [13].

ABA is accumulated in seeds during on-plant ripening and post-harvest ripening[14]. Studies on effects of external phytohormones on the seed germination and structural changes during germination demonstrated, in particular, that external ABA, unlike gibberellic acid (GA), inhibited the germination [15], reduced the seedling weight and inhibited $\alpha$-amylase in seeds [16]. There are genes which are responsible for ABA synthesis and control seed longevity [17]. Seed storage investigations showed a reduction in ABA content for some genotypes stored at $25{ }^{\circ} \mathrm{C}$ and for others - only at $5{ }^{\circ} \mathrm{C}$ [18]. The issues of the post-harvest seed storage temperature effect on the content, metabolic and signaling pathways of ABA and GA are discussed.

Study purpose and objectives. Our purpose was to evaluate the longevity of rye seeds with $5-7 \%$ of moisture content after storage at unregulated temperature $\left(4{ }^{\circ} \mathrm{C}\right.$ and $20{ }^{\circ} \mathrm{C}$ ) under the eastern forest-steppe of conditions in Ukraine, to assess the possibility of seed longevity predicting from accelerated aging data and ABA content.

Materials and methods. Seeds of rye lines L.90691 A, L.1201 B (grown in 2011) and Kharkivianka BK (grown in 2011 and 2012) were taken as the test material. Plants were grown at the Experimental Base "Elitne" of the Plant Production Institute n.a. V.Ya. Yuriev of NAAS (eastern forest-steppe of Ukraine) in accordance with agrotechnical requirements [19].

The laboratory received seeds with moisture content of $12 \%$ for tests at the beginning of 2014. Prior to this, seeds were stored indoors at uncontrolled temperature and air humidity for 2.5 and 1.5 years, respectively. The test seeds were air-dried at temperatures not exceeding $25^{\circ} \mathrm{C}$ and at relative air humidity of $25 \%$ using a dehumidifier Munters (Sweden) to a target moisture content of 5,6 and 7\%. Seeds with these moisture contents were stored in sealed containers (glass bottles or multilayer foil packages) in depositories at unregulated temperature (UT), $+4{ }^{\circ} \mathrm{C}$ or $-20^{\circ} \mathrm{C}$ for 12,24 and 36 months. The average annual temperature in the repository with unregulated temperature of the eastern forest-steppe of Ukraine was $9.5^{\circ} \mathrm{C}$.

The rye seed germinability was determined by germinating at $20^{\circ} \mathrm{C}$ in compliance with the recommendations for seed testing [20]. The seedling length was measured on the day of germinability determination. Accelerated aging was performed at $37{ }^{\circ} \mathrm{C}$ for 18 months for seeds with moisture content of 5,6 and $7 \%$ [21]. The accelerated aging effect was assessed after 12 and 18 months of the experiment. To study one of the mechanisms of the germination dynamics and seed longevity, the ABA content, which may change during storage, in particular, decrease during storage at low and negative temperatures, was determined [22, 23]. The ABA content was determined after 12 months of storage [24].

Data were statistically processed to compare the seed germinability under different storage conditions with the initial values of the same samples. We used t-test to assess differences in the seed germinability between experimental and control samples and to compare the seedlings lengths in the experimental and control groups. We studied the relationship between the ABA level and seed longevity by correlation between the ABA level and seed germinability. Statistical calculations [15] were carried out using Excel.

Results and discussion. The germinability of L.90691A seeds with 5\%, 6\% and 7\% of moisture content remained either unchanged, i.e. did not differ from the initial values of $56 \%, 51 \%$ 
and $48 \%$, respectively, or there were some variations after 12-months storage of seeds. The seed germinability decreased by about $15 \%$ and $10 \%$ after storage of seeds with moisture content of $5 \%$ and $7 \%$, respectively, under unregulated conditions. The germinability of seeds with moisture content of $5 \%$ and $6 \%$ decreased by $10 \%$ and $14 \%$, respectively after storage at $+4^{\circ} \mathrm{C}$.

After further storage for up to 24 months, the previously observed downward trends in the germinability were noted: by $20 \%$ and lower were at UT and moisture content of $5 \%$ and $7 \%$ and by $16 \%$ in the $-20^{\circ} \mathrm{C}$ group. A decrease in germinability of seeds with moisture content of $5 \%$ can be due to the need for a longer adaptation of seeds at room temperature after storage at $-20^{\circ} \mathrm{C}$.

A significant decrease in the germinability of seeds with $6 \%$ moisture content was observed after storage at unregulated temperature for 36 months. The germinability did not differ from the initial value for seeds with $5 \%$ and $7 \%$ moisture content. The germinability of seeds with $5 \%$ moisture content remained unchanged at $4{ }^{\circ} \mathrm{C}$. The germinability of seeds with $6 \%$ and $7 \%$ moisture content was lower by 16 and $7 \%$ than the initial values, respectively. The germinability of seeds with $5 \%$ moisture content decreased by $20 \%$ for seeds stored at $-20^{\circ} \mathrm{C}$. The germinability of seeds with 6 and $7 \%$ moisture content did not differ significantly from the initial values.

Thus, the best storage regimens for rye line L.90691A seeds with reduced initial seed germinability were $4^{\circ} \mathrm{C}$ and UT (eastern forest-steppe of Ukraine) for seeds with $5 \%$ moisture content and $-20^{\circ} \mathrm{C}$ for seeds with $6 \%$ and $7 \%$ moisture content.

The initial germinability of L.1201 B seeds with 5\%, 6\% and 7\% moisture content was $96 \%, 95 \%$ and $98 \%$, respectively. After 12-month storage at UT, the germinability of seeds with 5 and $6 \%$ moisture content was about $80 \%$. The germinability of seeds with $7 \%$ moisture content was $91 \%$, which was significantly lower than the initial germinability.

The seed germinability was also about $80 \%$, and there was not significant difference between samples with different moisture content after storage during this period at $4{ }^{\circ} \mathrm{C}$ and $-20^{\circ} \mathrm{C}$. It is noteworthy that there were no advantages of $-20^{\circ} \mathrm{C}$ storage of rye seeds with $5-7 \%$ moisture content during this period compared with storage at $4^{\circ} \mathrm{C}$ and NT.

Line L.1201B seeds with 5\%, 6\% and 7\% moisture content stored at unregulated temperature for 24 monthes had the average germinability of $95 \%$. There were no significant differences in the germinability between samples with $5 \%, 6 \%$ and $7 \%$ moisture content. The germinability of seeds with the same moisture content stored at $4^{\circ} \mathrm{C}$ did not significantly differ from that of seeds stored at UT (90\%). The germinability of L.1201B seeds with the same moisture level stored at $-20^{\circ} \mathrm{C}$ for 24 months did not exceed the germinability of seeds stored at UT and $+4^{\circ} \mathrm{C}$ for the same period. The germinability was $80 \%, 86 \%, 92 \%$ for seeds with $5 \%, 6 \%, 7 \%$ moisture content, respectively.

These germination indices were lower than those of seeds stored at UT and $4{ }^{\circ} \mathrm{C}$. This may be attributed to features of seed sprouting with moisture content 5 and $6 \%$ after storage at a negative temperature.Thus, storage of rye line L.1201 B seeds with 5\%,6\% and 7\% moisture content at UT in the eastern forest-steppe of Ukraine, $+4{ }^{\circ} \mathrm{C}$ and $-20^{\circ} \mathrm{C}$ for 24 months had no advantages over $-20^{\circ} \mathrm{C}$ storage of seeds with moisture content within $5-7 \%$. In some cases, there was even a decrease in the germinability of seeds with $5 \%$ moisture content, in particular, after $-20^{\circ} \mathrm{C}$ storage. A similar decrease in the germinability of seeds with $5 \%$ moisture content stored at $-20^{\circ} \mathrm{C}$ was observed for L.90691 A line. This demonstrates the importance of seed moisture selection, even in the range of 5-7\% at various storage temperatures.

12-month storage of Kharkivianka BK rye seeds at UT decreased the germinability by 8 and $10 \%$ for samples with 5 and $6 \%$ moisture content, respectively, and did not significantly affect the seed germinability of a sample with $7 \%$ moisture content (Table 1). Storage of Kharkivianka BK seeds with 5\% and 6\% moisture content at $4^{\circ} \mathrm{C}$ did not significantly change their germinability compared to the initial value. The seed germinability of this accession with $7 \%$ moisture content decreased significantly - by $9 \%$. After storage of seeds with any moisture levels at $-20^{\circ} \mathrm{C}$, we observed a significant decrease in the germinability by $13-39 \%$. Subsequent storage for up to 24 months did not lead to further significant changes in the germinability of seeds with any moisture contents stored both at UT at $4^{\circ} \mathrm{C}$ or $-20^{\circ} \mathrm{C}$. The seed germinability of these samples was significantly lower than the initial value. Further storage for up to 36 
months did not lead to significant further changes in the germinability either, except for seeds having $7 \%$ moisture content and stored at $-20^{\circ} \mathrm{C}$. In this case, the germinability decreased by $35 \%$ compared to the germinability after 24-month storage. The experiments on Kharkivianka BK storage indicate no advantages of seed storage at $-20^{\circ} \mathrm{C}$ over UT conditions of the eastern forest-steppe of Ukraine when the moisture content of seeds was 5-7\%. In some cases, the advantages of storing seeds with moisture content of $5-6 \%$ at $+4^{\circ} \mathrm{C}$ were recorded. The lack of advantages of storing rye seeds at $-20^{\circ} \mathrm{C}$ for three years can be attributed to the low average storage temperature in the chamber with unregulated temperature and, possibly, longer recovery of rye seeds from freezing.

Table 1

Post-storage germinability of Kharkivianka BK rye seeds

\begin{tabular}{lccc}
\hline \multicolumn{1}{c}{$\begin{array}{c}\text { Storage period at various } \\
\text { temperatures, months }\end{array}$} & \multicolumn{3}{c}{ Germinability of seeds with moisture content, \% } \\
\cline { 2 - 4 } & 5 & 6 & 7 \\
\hline Original germination & $98.3^{*}$ & 96.0 & 95.7 \\
$\mathrm{UT}^{*}, 12$ months & $89.9^{*}$ & $86.4^{*}$ & 92.2 \\
$4^{\circ} \mathrm{C}, 12$ months & $98.3^{* *}$ & 89.0 & $86.7^{*}$ \\
$-20^{\circ} \mathrm{C}, 12$ months & $77.3^{*}$ & $56.7^{*}$ & $83.1^{*}$ \\
$\mathrm{UT}, 24$ months & $87.4^{* *}$ & $84.8^{*}$ & $81.6^{*}$ \\
$4^{\circ} \mathrm{C}, 24$ months & $85.0^{*}$ & $86.4^{*}$ & $85.7^{*}$ \\
$-20^{\circ} \mathrm{C}, 24$ months & $87.3^{*}$ & $86.6^{*}$ & $85.5^{*}$ \\
$\mathrm{UT}, 36$ months & $86.2^{*}$ & $82.1^{*}$ & $88.4^{*}$ \\
$4^{\circ} \mathrm{C}, 36$ months & $62.5^{*}$ & $84^{*}$ & $89.0^{*}$ \\
$-20^{\circ} \mathrm{C}, 36$ months & $85.0^{* *}$ & $83.5^{*}$ & $50.7^{*}$ \\
\hline
\end{tabular}

*significant decrease compared to the initial value;

significant difference compared to $7 \%$ moisture content.

Only in some cases, the germinability of seeds with $5 \%$ moisture content was significantly higher than that of seeds with $7 \%$ moisture content.

The experiments on accelerated aging of Kharkivyanka BK seeds with 5\%,6\% and 7\% moisture content were carried out, where the seeds were stored for 4, 12, 18 months under the specified model conditions at $37^{\circ} \mathrm{C}$. The advantages of storage of seeds with 5 and $6 \%$ moisture content under these conditions over seeds with $7 \%$ moisture content were proven (Table 2). Our results showed that this accelerated aging method could be used to roughly predict the seed viability. In particular, there was a strong positive correlation between the storage of seeds with $7 \%$ moisture content under accelerated aging conditions for 12 and 18 months and 24- and 36- month storage at $-20{ }^{\circ} \mathrm{C}$ for seeds with the same moisture content $(\mathrm{r}=0.99)$.

Table 2

Post-accelerated ageing germinability of Kharkivianka BK seeds

\begin{tabular}{lccc}
\hline \multirow{2}{*}{ Accelerated } & \multicolumn{3}{c}{ Germinability of seeds with moisture content, \% } \\
\cline { 2 - 4 } \multicolumn{1}{c}{ ageing period, months } & 5 & 6 & 7 \\
\hline 4 months & 98.3 & 96.0 & 95.7 \\
12 months & $88.4^{* \cdot * *}$ & $87.3^{*} \cdot * *$ & $79.3^{*}$ \\
18 months & $59.5^{* * * *}$ & $63.0^{*} \cdot * *$ & $24.4^{*}$ \\
\hline
\end{tabular}

* significant decrease compared to the initial value;

significant difference compared to $7 \%$ moisture content.

After 12-month storage of seeds at unregulated temperature, the total length of L.90691A line seedlings grown from seeds with 5, 6 and $7 \%$ moisture content was not significantly different from the initial value in most cases and averaged $19.3 \mathrm{~cm}$. However, the total lengths of seedlings from seeds with moisture content of $6 \%$ and roots from seeds with moisture content of $7 \%$ significantly exceeded the initial values of $15.3 \mathrm{~cm}$ by $3-4 \mathrm{~cm}$. A similar variation trend in the seedling length was observed after 12 months of storage at $4^{\circ} \mathrm{C}$, but the total average length of seedlings was shorter by $1 \mathrm{~cm}$, i.e. 18 
$\mathrm{cm}$. After 12 - month storage of seeds at $-20{ }^{\circ} \mathrm{C}$, the total length of seedlings grown from seeds with various moisture content did not differ significantly $(\mathrm{t}<1.98)$. The seedlings from seeds with $5 \%$ moisture content were the longest (20 cm vs. the post-storage average length of $17.6 \mathrm{~cm}$ for this regimen).

Thus, we suppose that for 12-month storage of rye line L.90691 seeds 5\% moisture content and $-20^{\circ} \mathrm{C}$ were the best regimen. This regimen increased the seedling length almost by $3 \mathrm{~cm}$ $(\mathrm{t}=4.2)$, significantly exceeding the storage of seeds with $7 \%$ moisture content $(\mathrm{t}=2.1)$ under the same conditions by this parameter. Storage of seeds with 5, 6 and $7 \%$ moisture content at UT and $4^{\circ} \mathrm{C}$ did not shorten seedlings.

After 24-month storage, the coleoptile length averaged $12.4 \mathrm{~cm}$, which was lower than the initial coleoptile length by $3 \mathrm{~cm}(\mathrm{t}=-3.1)$. There were no significant differences in the seedling length between the samples with 5, 6, and $7 \%$ moisture content and the three storage temperatures (unregulated temperature, $4{ }^{\circ} \mathrm{C},-20{ }^{\circ} \mathrm{C}$ ). 24-month storage of line L.90691A seeds with 5$7 \%$ moisture content at $4{ }^{\circ} \mathrm{C}$ or $-20{ }^{\circ} \mathrm{C}$ was not superior to storage at unregulated temperature of the eastern forest-steppe of Ukraine, where the average annual temperature is $9^{\circ} \mathrm{C}$, in terms of seed viability.

The seedlings length after 36-month storage did not differ significantly from that after 24month storage under corresponding experimental conditions. This trend was observed mainly for all samples with 5, 6 and 7\% moisture content and hel three storage temperatures (unregulated temperature, $4{ }^{\circ} \mathrm{C},-20{ }^{\circ} \mathrm{C}$ ). After $-20{ }^{\circ} \mathrm{C}$ storage of seeds with $5 \%$ moisture content the seedlings were only longer by $2.8 \mathrm{~cm}$ than in the previous group after 24-month storage.

Measurement of L.1201 B line seedlings grown from seeds with 5, 6 and $7 \%$ moisture content showed no significant difference in the seedling length, both after 12 and after 18 months of storage, regardless of the storage temperature. The total length of seedlings on the day of germinability determination was about $20 \mathrm{~cm}$. The seedling length/root length ratio was 0.8 . After 24-month storage, the seedlings were shorter, averaging $14.3 \mathrm{~cm}(\mathrm{t}>1.98)$. The seedling length/root length ratio was 0.6. Within the same storage regimen, the seedling length did not differ in most cases, regardless of moisturecontent in seeds. The length of seedlings from seeds with $5 \%$ moisture content stored at $-20{ }^{\circ} \mathrm{C}$ significantly exceeded that of seedlings from seeds with the same moisture content stored at UT ( $\mathrm{t}=2.6$ for coleoptile with leaves). The seedlings (up to $17 \mathrm{~cm}$ ) from seeds with $5 \%$ moisture content stored at $-20{ }^{\circ} \mathrm{C}$ were longer than the seedlings from seeds with $7 \%$ moisture content stored at the same temperature $(\mathrm{t}=2.3$ for root and $\mathrm{t}=3.2$ for coleoptile with leaves). Our results on the seedling length show that for two-year storage of L.1201B line seeds $-20{ }^{\circ} \mathrm{C}$ and 5\% moisture content were the optimal parameters. 12-month storage of Kharkivianka BK seeds with 5, 6 and $7 \%$ moisture content at UT did not induce significant differences both in the total seedling length and in root length (however the seedlings were longer than at baseline in most cases, averaging $21.2 \mathrm{~cm}$ ) (Table 3).

There were no differences in the length of seedlings grown from seeds of this variety stored at $4{ }^{\circ} \mathrm{C}$ with 5, 6 and $7 \%$ moisture content. The total length of seedlings was $20.6 \mathrm{~cm}$ and did not differ significantly from that of seedlings from seeds stored at unregulated temperature.

The length of Kharkivianka BK seedlings from seeds stored with 5, 6 and $7 \%$ moisture content at $-20{ }^{\circ} \mathrm{C}$ for 12 months did not differ significantly, regardless of moisture content, except for $7 \%$ moisture content, where the seedling were almost by $3 \mathrm{~cm}$ shorter ( $>>0.05)$ than those from seeds with $5 \%$ and $6 \%$ moisture content. This may be attributed to the inhibitory effect of negative temperature storage of seeds with $7 \%$ moisture content on the seed germination.

Kharkivianka BK seedlings from seeds stored for 24 months with 5, 6 and $7 \%$ moisture content at unregulated temperature and $-20{ }^{\circ} \mathrm{C}$ did not differ by the total seedling length one from another, although in the $7 \%$ moisture content group the seedling were almost by $3 \mathrm{~cm}$ shorter than the pre-storage value ( $p>0.05$ ). This may be due to the suppressive effect of negative temperature on the germination of seeds stored with $7 \%$ moisture content. After 24-month storage, Kharkivianka BK seeds with moisture content of 5 and $7 \%$ stored at UT and $-20{ }^{\circ} \mathrm{C}$ did not differ in the total length of seedlings. Variations in the length of seedlings from seeds with $6 \%$ moisture content under different storage modes were observed. In this case, the seedlings were by 
$1 \mathrm{~cm}$ shorter than those from seeds with higher or lower moisture content stored at unregulated temperature and $4^{\circ} \mathrm{C}$ and by $1.5 \mathrm{~cm}$ higher than those from seeds with $7 \%$ moisture content stored at $-20^{\circ} \mathrm{C}$. After storage at unregulated temperature and $+4^{\circ} \mathrm{C}$, seeds with $7 \%$ moisture content produced seedlings and roots that were significantly shorter than pre-storage ones. The seedling length was substantially lower than the initial value when seeds were stored at $-20{ }^{\circ} \mathrm{C}$ with $7 \%$ moisture content. Thus, 2-year storage of Kharkivyanka BK seeds with $5 \%$ moisture content did not affect the seedling length under the corresponding storage conditions (unregulated temperature, $4^{\circ} \mathrm{C},-20^{\circ} \mathrm{C}$ ). Suppression of the length of seedling from seeds with $6 \%$ moisture content was observed in some cases only. The storage of seeds with $7 \%$ moisture content at the three temperatures inhibited both coleoptile and root growth (Table 3 ).

After 36-month storage at UT, $4^{\circ} \mathrm{C}$, or $-20^{\circ} \mathrm{C}$ ), no seedling growth inhibition was observed in Kharkivianka BK for seeds stored with $5 \%$ moisture content. After $4^{\circ} \mathrm{C}$ and $-20^{\circ} \mathrm{C}$ storage, even the seedlings were even longer by about $1 \mathrm{~cm}$ (Table 3 ). We believe that a stimulating effect of storage at low positive and negative temperatures is possible. We observed no significant differences in the length of seedlings from seeds stored with $6 \%$ moisture content at UT or at $4^{\circ} \mathrm{C}$. After $-20^{\circ} \mathrm{C}$ storage, the seedlings were shorter by more than $1 \mathrm{~cm}$. The seedlings from seeds with $7 \%$ moisture content which were stored for 36 months at the three temperatures (unregulated temperature, $4^{\circ} \mathrm{C},-20^{\circ} \mathrm{C}$ ) were by $1 \mathrm{~cm}$ shorter than the pre-storage seedlings $(\mathrm{p}>0.05)$.

Thus, the rye seedling length, which is an indicator of physiological and biochemical processes involved in the seedlings formation and may be affected by seed storage conditions, did not demonstrate significant differences between 2-year storage of seeds with the test moisture content at unregulated temperature and $4^{\circ} \mathrm{C}$.

Table 3

Kharkivianka BK seedling and root lengths

\begin{tabular}{|c|c|c|c|c|c|c|}
\hline \multirow{3}{*}{$\begin{array}{l}\text { Storage, dura- } \\
\text { tion (months), } \\
\text { temperature }\end{array}$} & \multicolumn{6}{|c|}{ Length $(\mathrm{cm})$ of seedlings from seeds with moisture content, $\%$} \\
\hline & \multicolumn{2}{|c|}{5} & \multicolumn{2}{|c|}{6} & \multicolumn{2}{|c|}{7} \\
\hline & $\begin{array}{l}\text { coleoptile } \\
\text { length }\end{array}$ & root length & $\begin{array}{l}\text { coleoptile } \\
\text { length }\end{array}$ & root length & $\begin{array}{l}\text { coleoptile } \\
\text { length }\end{array}$ & root length \\
\hline Initial & 7.7 & 7.6 & 7.5 & 7.5 & 8.2 & 9.6 \\
\hline UT, 12 months & $11.7 *$ & $10.2 *$ & $10.8 *$ & $9.8 *$ & $11.7 *$ & 9.4 \\
\hline $4^{\circ} \mathrm{C}, 12$ months & $11.5^{*}$ & $9.0^{*}$ & $10.0 *$ & 12.2 & $9.5^{*}$ & 9.5 \\
\hline $\begin{array}{l}-20^{\circ} \mathrm{C}, 12 \\
\text { months }\end{array}$ & $11.4^{*} \cdot * *$ & $10.4^{*}$ & $10.8 * * * *$ & $8.8^{*}$ & 7.5 & 8.6 \\
\hline UT, 24 months & 7.2 & 7.6 & $5.8 * * *$ & 6.9 & 6.6 & $7.1^{*}$ \\
\hline $4^{\circ} \mathrm{C}, 24$ months & 7.3 & 8.2 & $4.3 * * * *$ & $6.6 * *$ & 7.0 & $8.1 *$ \\
\hline $\begin{array}{l}-20^{\circ} \mathrm{C}, 24 \\
\text { months }\end{array}$ & 7.7 & 7.6 & $8.6 * *$ & 7.8 & $7.1 *$ & $8.2 *$ \\
\hline UT, 36 months & $8.1 * *$ & $7.0 * *$ & $7.5 * *$ & $7.3 * *$ & $5.2 *$ & $5.7 *$ \\
\hline $4^{\circ} \mathrm{C}, 36$ months & $9.0^{*}$ & 8.6 & 7.4 & 8.0 & 8.0 & $7.1 *$ \\
\hline $\begin{array}{l}-20^{\circ} \mathrm{C}, 36 \\
\text { months }\end{array}$ & $8.6^{*}$ & $8.3 * *$ & $5.9 *$ & $6.3 *$ & $6.8^{*}$ & $6.7 *$ \\
\hline
\end{tabular}

* significant decrease compared to the initial value;

significant difference compared to $7 \%$ moisture content

Analysis of ABA activity indicates a lower ABA content in seeds after lower storage temperatures(average $r=0.69$ ) (Table 4 ). The highest ABA content was found in seeds with $6 \%$ moisture content, and the lowest - with $5 \%$ moisture content, i.e. it is expected that seeds with $5 \%$ moisture content will germinate faster than those with $6 \%$ or with $7 \%$ moisture content. There was no strong correlation between the ABA content or seed longevity after 36-month storage of Kharkivianka BK seeds ( $\mathrm{r}=0.33)$ (Table 4). 
Storage regimen effect on ABA activityrye in rye seeds

\begin{tabular}{lcccc}
\hline \multirow{2}{*}{$\begin{array}{c}\text { Accession, } \\
\text { storage temperature }\end{array}$} & $\begin{array}{c}\text { ABA activity (\%) in seeds with various } \\
\text { moisture content, \% }\end{array}$ & $\begin{array}{c}\text { Correlation between the } \\
\text { storage temperature and } \\
\text { ABA content }\end{array}$ \\
\cline { 2 - 4 } & 5 & 6 & 7 & $0.84^{*}$ \\
\hline L.90691 A, UT & 481.0 & 490.5 & 452.4 & \\
L.90691 A, $4^{\circ} \mathrm{C}$ & 214.3 & 304.8 & 252.4 & \\
L.90691 A, $-20^{\circ} \mathrm{C}$ & 104.8 & 190.5 & 119.0 & 0.69 \\
L.1201 3C, UT & 133.3 & 247.6 & 300.0 & 0.64 \\
L.1201 3C, $-20^{\circ} \mathrm{C}$ & 119.0 & 142.9 & 138.1 & \\
Kharkivianka, UT & 285.7 & 409.5 & 433.3 & \\
Kharkivianka, $4^{\circ} \mathrm{C}$ & 142.9 & 347.6 & 133.3 & $0.69^{*}$ \\
Kharkivianka, $-20^{\circ} \mathrm{C}$ & 123.8 & 157.1 & 181.0 & \\
Average & 200.6 & 286.3 & 251.2 & \\
\hline
\end{tabular}

* significant at 0.05 significance level

The variation of the germinability of 90691 A seeds with moisture content of $5 \%, 6 \%$ and $7 \%$ after storage for 12 months, depending on the storage conditions, is difficult to explain unambiguously, because there is no clear direct trend in the germinability decrease dependence on the moisture content and storage conditions (unregulated temperature, $4^{\circ} \mathrm{C},-20^{\circ} \mathrm{C}$ ). $\mathrm{We}$ assume that the initial germinability below $100 \%$ was decreased after storage only in certain cases due to the influence of these factors on the seed physiological condition in a particular variant of the experiment. For example, the germinability of seeds with $7 \%$ moisture content decreased after storage at unregulated temperature or at $+4^{\circ} \mathrm{C}$. There was a negative effect of excess moisture levels over $6 \%$. The germinability of 90691A seeds with $5 \%$ moisture content decreased under the same storage conditions, which could be due to the excessively dried (6\%) seeds of this physiological state. Similar trends persisted upon 24-month storage at UT. A decrease in the germinability of seeds with $5 \%$ moisture content after storage for 24 months at $-20{ }^{\circ} \mathrm{C}$ may be attributed to the need for a longer period of seed adaptation before germination at room temperature after storage at $-20{ }^{\circ} \mathrm{C}$. A similar explanation can be offered for storage of seeds with $5 \%$ moisture content for 36 months at $-20^{\circ} \mathrm{C}$.

The absence of significant differences in the germinability of L.1201B seeds with $5 \%$, $6 \%$ and $7 \%$ moisture content which were stored at UT, $4^{\circ} \mathrm{C}$, or at $-20^{\circ} \mathrm{C}$ for 12 and 24 months indicates that the test storage modes influence similarly at the initial stages of storage. At the same time, it is necessary to pay attention to the importance of release of seeds with $5 \%$ moisture content stored at $-20^{\circ} \mathrm{C}$ from dormancy.

Analysis of the germinability of Kharkivianka BK seeds with 5-7 \% moisture content after storage for 36 months showed that, despite variations in the storage regimens, there were no consistent advantages of $-20^{\circ} \mathrm{C}$ storage over the unregulated conditions of the eastern forest-steppe of Ukraine. In some cases, the benefits of storage of seeds with 5-6\% moisture content at $4{ }^{\circ} \mathrm{C}$ were observed. The lack of benefits of rye seed storage at $-20{ }^{\circ} \mathrm{C}$ for three years may be explained by the low average storage temperature in the unregulated temperature chamber and, possibly, by the prolonged release of seeds from freezing.

An important result of this work is the evidance of possibility to approximately predict the germinability of seeds stored at $-20^{\circ} \mathrm{C}$ from a positive correlation $(r=0.99)$. This information was received from analysis of accelerated aging of rye seeds with $7 \%$ moisture at $37^{\circ} \mathrm{C}$ for 12 months or longer. We believe that it is easier to make such a prediction when moisture content is $7 \%$ than it is $5 \%$ or $6 \%$, because $7 \%$ moisture content is supposed to be associated with a less deeper anabiosis, which should contribute to the aging process. Accelerated aging modes with higher temperatures and seed moisture levels were not appropriate for our purpose, since the seed metabolism under such storage conditions, for example, $75 \%$ $\mathrm{RH}, 65^{\circ} \mathrm{C}$ and above, is different from that under conditions with $7 \%$ moisture content, $4{ }^{\circ} \mathrm{C}$, which are often used for middle-term storage. 
Slight fluctuations and absence of obvious trends in the seedling growth after seed storage under the various experimental conditions can attest to absence of significant influence of the used storage conditions on physiological and biochemical processes involved in the seedling formation. The stimulating effect was observed for the seedling length after storage of L.90691A and L.1201B seeds with $5 \%$ moisture content at $-20^{\circ} \mathrm{C}$, indicating a favorable effect of this regimen on physiological and biochemical processes involved in the seedling formation. Thus, the rye seedling length, which is an indicator of physiological and biochemical processes involved in the seedling formation and may be affected by the seed storage conditions, demonstrated no significant advantages of 2-year storage of seeds with the investigated moisture content at UT and $4^{\circ} \mathrm{C}$. Despite some variations, the shortest seedlings were those from seeds with $7 \%$ moisture content stored at UT for three years $(t>1.98)$ (Table 3).

There was a linear correlation between the ABA content and seed storage temperature. The ABA content decreased as the average storage temperature $\left(9^{\circ} \mathrm{C}, 4^{\circ} \mathrm{C},-20^{\circ} \mathrm{C}\right)$ decreased: L.90691 A ( $\mathrm{r}=0.84)$, L.1201 B ( $\mathrm{r}=0.69)$, Kharkivianka ( $\mathrm{r}=0.64)$ (Table 4). Correlation calculations at the significance level of 0.05 showed a significant correlation between the storage temperature and ABA content for L.90691 A $(\mathrm{t}=4.1)$. The correlation significance level for Kharkivianka BK is only 0.1 . The average correlation between the storage temperature and ABA content was found to be $r=0.69$ for the three accessions under investigation.

The lower storage temperature was, the lower ABA level became, which is expected, because it is known that the ABA level decreases during storage of seeds, especially at low temperatures [Mao \& Sun, 2015; Rodriguez et al., 2018]. Despite information about genes responsible for $\mathrm{ABA}$ synthesis and seed longevity regulation [Mao \& Sun, 2015], no strong correlation between the ABA content and seed longevity was noted. This indicates that the ABA content in seeds is not the only factor affecting the seed ability to germinate after middle- and long-term storage.

Conclusions. Thus, the conducted study on the rye seed storage revealed no consistent relationship between the germinability of seeds with 5-7\% moisture content and temperature of storage for up to 36 months. At this moisture level, after 3-year storage, no advantages of low temperatures over unregulated temperature were recorded. The shortest rye seedlings from seeds stored with $7 \%$ moisture content at unregulated temperature for 36 months.

The results of accelerated aging of seeds with $7 \%$ seed moisture content better predict the seed longevity.

The ABA content in seeds cannot be a predictive marker for the seed longevity, despite the fact that the ABA activity reduced after seed storage at negative temperature.

\section{References}

1. Khoroshailov NG, Zhukova NV. The experience of long-term seed storage. Trudy po prikladnoi botanike, genetike i selektsii. 1973. 49(3): 269-79.

2. DSTU-4522:2006. Rye. Specifications: [Internet] [Available from]: URL: http://af.gov.ua/images/stories/files/dsty4522-2006.pdf [date cited 10.10.19].

3. Genebank Standards for Plant Genetic Resources for Food and Agriculture. Commissionon Genetic Resources for Food and Agriculture. Rome. 2014. [Internet] [Available from]: URL: http://www.fao.org/3/a-i3704e.pdf [date cited 12.11.19].

4. Barzali M, Lohwasser U, Niedzielski M, Börner A. Effects of different temperatures and atmospheres on seed and seedling traits in a long-term storage experiment on rye (Secale cereale L.). Seed Science and Technology. 2005; 33(3): 713-21. DOI: 10.15258/sst.2005.33.3.19.

5. Hong TD, Ellis RH. A protocol to determine seed storage behavior. IPGR Technical bulletin NO.1. The University of Reading; 1996. 64 p.

6. Roberts EH, Ellis RH. Water and seed survival. Annals of Botany. 1989; 63: 39-52.

7. Zadorozhna OA, Herasimov MV, Shyianova TP. Features of long term seeds storage of rye genepool accessions. Genetičnì resursi roslin. 2014; 14: 105-14. 
8. Whitehouse K, Hay F, Ellis R. Improvement in rice seed storage longevity from high temperature drying is a consistent positive function of harvest moisture content above a critical value. Seed Science Research. 2018; 28(32): 332-39. DOI:10.1017/S0960258518000211.

9. Alekseichuk GN. The vigour of cereals seed growth and its evaluation by the method of accelerated aging. Minsk: Pravo i ekonomika. 2009. 44 p.

10.Walters C, Engels J, Walters C, Engels J. The effects of storing seeds under extremely dry conditions. URL: https://www.bioversityinternational.org/ fileadmin/bioversity/ publications/Web_version/243/ch02.htm [date cited 10.11.18].

11. Zadorozhna OA, Shyianova TP, Gerasimov MV. Influence of different storage conditions on rye (Secale cereale L.) Seed germination and antioxidant activity. Genetičnì resursi roslin. 2016; 18: 104-18.

12. Zadorozhna O. Some supplemental recommendations for the optimum moisture content of wheat seed for long-term storage. Annual Wheat Newsletter. Kansas State University. 2001; 47: 203-204.

13. Rodríguez-Gacio MC, Matilla-Vázquez MA, Matilla1 AJ. Seed dormancy and ABA signaling. Plant Signaling \& Behavior. 2009; 4(11): 1035-1048. DOI: 10.4161/psb.4.11.9902.

14. Nambara E, Okamoto M, Tatematsu K, Yano R, Seo M, Kamiya Y. Abscisic acid and the control of seed dormancy and germination. Seed Science Research. 2010; 20: 55-67.

15. Abts W, Van De Poel B. Vandenbussche B., Proft, DeProfit M. Abscisic acid inhibits germination and indirectly delays ethylene biosynthesis of Beta vulgaris. Seed Science and Technology. 2015; 43 (2): 156-167. DOI: 10.15258/sst.2015.43.2.18.

16. Wang LL, Chen XY, Yang Y, Wang Z, Xiong F. Effects of exogenous gibberellic acid and abscisic acid on germination, amylases, and endosperm structure of germinating wheat seeds. Seed Science and Technology. 2016; 44(1): 64-76.

17. Mao Z, Sun W. Arabidopsis seed-specific vacuolar aquaporins are involved in maintaining seed longevity under the control of abscisic acid insensitive. Journal of Experimental Botany. 2015; 66(15): 4781-4794. DOI: 10.1093/jxb/erv244.

18. Rodriguez M, Bodrone M, Castellari M, Batlla D. Effect of storage temperature on dormancy release of sunflower (Helianthus annuus) achenes. Seed Science Research. 2018; 28(2): 101111. DOI: $10.1017 /$ S0960258518000065.

19. Methods of state testing of plant varieties for suitability for distribution in Ukraine. Protection of plant variety rights. Kyiv: Alefa; 2003. P. 191-203.

20. International rules for seed testing. 1984. Moscow: Kolos; $311 \mathrm{p}$.

21. Likhachev BS, Musorina LI. Biulleten VIR. 1978; 77: 57-62.

22. Nikolaeva MG Obrucheva NV.,editors. Physiology and biochemistry of seed dormancy and germination 1982. Moscow:Kolos; 1982. 495 p.

23. Leida C, Conejero A, Arbona V, Gómez-Cadenas A, Llácer G. Chilling-dependent release of seed and bud dormancy in peach associates to common changes in gene expression. URL: http://www.ncbi.nlm.nih.gov /pubmed/22590512 [date cited 20.10.19].

24. Savinskii SV, Dragovoz IV, Pedchenko VK. Determination of the content of zeatin, indole3 -acetic and abscisic acids in one plant sample by high-sensitivity liquid chromatography. Fiziolohiia i biokhimiia kulturnykh rastenii. 1991; 23(6): 611-618.

25. Volf VG. Statistical processing of experimental data. Moscow: Kolos, 1966. 255 p.

\section{Список використаних джерел}

1. Хорошайлов Н.Г., Жукова Н.В. Длительное хранение коллекционных образцов семян// Труды по прикладной ботанике, генетике и селекции. 1973. Т. 49. Вып. 3 .С. 269-279.

2. ДСТУ-4522:2006. Жито. Технічні умови: URL: http://af.gov.ua/images/stories/files/dsty 4522-2006.pdf (дата звернення 10.10.19).

3. Genebank Standards for Plant Genetic Resources for Food and Agriculture. Commissionon Genetic Resources for Food and Agriculture. Rome. 2014. URL: http://www.fao.org/3/ai3704e.pdf (дата звернення 12.11.19). 
4. Barzali M., Lohwasser U., Niedzielski M., Börner A. Effects of different temperatures and atmospheres on seed and seedling traits in a long-term storage experiment on rye (Secale cereale L.). Seed Science and Technology. 2005. V. 33. № 3. P. 713-721. DOI: 10.15258/sst.2005.33.3.19.

5. Hong T.D., Ellis R.H. A protocol to determine seed storage behavior. IPGR Technical bulletin NO.1. The University of Reading; 1996. 64 p.

6. Roberts E.H., Ellis R.H. Water and seed survival. Annals of Botany. 1989; 63. P. 39-52

7. Задорожна О.А., Шиянова Т.П., Герасимов М.В. Особливості довготривалого зберігання насіння зразків генофонду жита. Генетичні ресурси рослин. 2014. № 14. С. 105-114

8. Whitehouse K., Hay F., Ellis R. Improvement in rice seed storage longevity from high temperature drying is a consistent positive function of harvest moisture content above a critical value. Seed Science Research. 2018. V. 28(32). P. 332-339. DOI: 10.1017/S0960258518000211.

9. Алексейчук Г.Н. Сила роста семян зерновых культур и ее оценка методом ускоренного старения. Минск: ИООО «Право и экономика», 2009. 44 с.

10. Walters C., Engels J., Walters C., Engels J. The effects of storing seeds under extremely dry conditions. URL: https://www.bioversityinternational.org/ fileadmin/bioversity/ publications/Web_version/243/ch02.htm (дата звернення 10.11.18).

11. Zadorozhna O.A., Shyianova T.P., Gerasimov M.V. Influence of different storage conditions on rye (Secale cereale L.) Seed germination and antioxidant activity. Генетичні ресурси рослин. 2016. № 18. С. 104-118.

12. Zadorozhna O. Some supplemental recommendations for the optimum moisture content of wheat seed for long-term storage. Annual Wheat Newsletter. Kansas State University. 2001. No 47. P. 203-204.

13. Rodríguez-Gacio M.C., Matilla-Vázquez M.A., Matilla1 A.J. Seed dormancy and ABA signaling. Plant Signaling \& Behavior. 2009. V. 4. № 11. P. 1035-1048. DOI: 10.4161/psb.4.11.9902.

14. Nambara E., Okamoto M., Tatematsu K., Yano R., Seo M., Kamiya Y. Abscisic acid and the control of seed dormancy and germination. Seed Science Research. 2010. No 20. P. 55-67.

15. Abts W., Van De Poel B. Vandenbussche B., Proft, De Profit M. Abscisic acid inhibits germination and indirectly delays ethylene biosynthesis of Beta vulgaris. Seed Science and Technology. 2015. V. 43. № 2. P. 156-167. DOI: 10.15258/sst.2015.43.2.18.

16. Wang L.L., Chen X.Y., Yang Y., Wang Z., Xiong F. Effects of exogenous gibberellic acid and abscisic acid on germination, amylases, and endosperm structure of germinating wheat seeds. Seed Science and Technology. 2016. V. 44. № 1. P. 64-76.

17. Mao Z., Sun W. Arabidopsis seed-specific vacuolar aquaporins are involved in maintaining seed longevity under the control of abscisic acid insensitive. Journal of Experimental Botany. 2015. V. 66. № 15. P. 4781-4794. DOI: 10.1093/jxb/erv244.

18. Rodriguez M., Bodrone M., Castellari M., Batlla D. Effect of storage temperature on dormancy release of sunflower (Helianthus annuus) achenes. Seed Science Research. 2018. V. 28. № 2. P. 101-111. DOI: 10.1017/S0960258518000065.

19. Методика державного випробування сортів рослин на придатність до поширення в Україні. Охорона прав на сорти рослин. Київ: Алефа, 2003. С. 191-203.

20. Международные правила анализа семян. Москва: Колос, 1984. 311с.

21. Лихачев Б.С., Мусорина Л.И. Использование экстремальных условий хранения семян в моделировании процессов их старения. Бюллетень ВИР. 1978. Вып. 77. С. 57-62.

22. Физиология и биохимия покоя и прорастания семян / Под ред. М.Г. Николаевой и Н. В. Обручевой. Москва.: Колос, 1982. 495 с.

23. Leida C., Conejero A., Arbona V., Gómez-Cadenas A., Llácer G et al. Chilling-dependent release of seed and bud dormancy in peach associates to common changes in gene expression. URL: http://www.ncbi.nlm.nih.gov/pubmed/22590512.

24. Савинский С.В., Драговоз И.В., Педченко В.К. Определение содержания зеатина, индолил-3-уксусной и абсцизовой кислот в одной растительной пробе методом высокоэ- 
ффективной жидкостной хроматографи. Физиология и биохимия культурных растений. 1991. T. 23. № 6. С. 611-618.

25. Вольф В.Г. Статистическая обработка опытных даннях. М.: Колос, 1966. 255 с.

\section{ВПЛИВ РІЗНИХ РЕЖИМІВ ЗБЕРІГАННЯ НА ПРОРОСТАННЯ НАСІННЯ ЖИТА І ВMICT АБK}

Задорожна О.А. ${ }^{1}$, Сгоров Д.К. ${ }^{1}$, Жмурко В.В. ${ }^{2}$

${ }_{1}^{1}$ Інститут рослинництва ім. В.Я. Юр'єва НААН, Україна

${ }^{2}$ Національний університет ім. В.Н. Каразіна, Україна

Під час тривалого зберігання часто виникають певні труднощі з насінням жита (Secale cereale L.). Існують лише загальні рекомендації щодо способів зберігання насіння жита.

Мета. У даній роботі досліджено довговічність зразків насіння жита з вологістю 5-7\% під час зберігання при нерегульованій температурі в умовах східної частини Лісостепу України, $4{ }^{\circ} \mathrm{C}$ та $-20{ }^{\circ} \mathrm{C}$ та в умовах модельного досліду «прискорене старіння».

Матеріали та методи. «Прискорене старіння» проводили шляхом витримування насіння сорту Харків'янка з вологістю 5 \%, 6 \% і 7 \% протягом 12, 18 місяців у зазначених модельних умовах за $37^{\circ} \mathrm{C}$. Для досліджених зразків насіння оцінювали лабораторну схожість, довжина проростків та вміст абсцизової кислоти (АБК) в насіння для окремих варіантів досліду.

Обговорення результатів. Аналіз моніторингу схожості насіння жита через 12, 24 і 36 місяців зберігання свідчить по важливість зберігання насіння за вологості не вище 7 \%, досягнутої при відповідних режимах сушіння, причому для нерегульованих умов температури східного лісостепу України бажана вологість 5-6\%. За цього рівня вологості після трьох років зберігання не встановлено переваг низьких температур зберігання над нерегульованими. Найкращий фізіологічний стан проростків насіння жита після двох років зберігання спостерігався за вологості насіння $5 \%$ та температури зберігання $-20^{\circ} \mathrm{C}$.

Висновки. За результатами використаного режиму прискореного старіння насіння встановлено, що краще проводити прогнозування його довговічності насіння при вологості насіння $7 \%$. Аналіз вмісту АБК в насінні, що зберігалось за нерегульованій температури в умовах східного лісостепу України, $4^{\circ} \mathrm{C}$ та $-20^{\circ} \mathrm{C}$ за свідчить, що нижчий вміст в насінні АБК був при нижчої температурі зберігання, але за вмістом АБК не можливо було спрогнозувати довговічність насіння.

Ключові слова: насіння жита, зберігання, вміст вологи, довголіття, абсиизова кислота.

\section{ВЛИЯНИЕ РАЗЛИЧНЫХ РЕЖИМОВ ХРАНЕНИЯ НА ПРОРАСТАНИЕ СЕМЯН РЖИ И СОДЕРЖАНИЕ АБК}

Задорожная О.А. ${ }^{1}$, Егоров Д.К. ${ }^{1}$, Жмурко В.В. ${ }^{2}$

${ }^{1}$ Институт растениеводства им. В.Я. Юрьева НААН, Украина

${ }^{2}$ Национальный университет им. В.Н. Каразина, Украина

Во время длительного хранения часто возникают определенные трудности с семенами ржи (Secale cereale L.). Ранее были определены общие рекомендации относительно способов их хранения.

Цель исследования. В данной работе исследованы долговечность семян образцов ржи с влажностью 5-7\% при хранении при нерегулируемой температуре в условиях восточной Лесостепи Украины, $4{ }^{\circ} \mathrm{C}$ и $-20{ }^{\circ} \mathrm{C}$ и в условиях модельного опыта «ускоренное старение».

Материалы и методы. «Ускоренное старение» проводилось путем выдерживания семян сорта Харьковчанка с влажностью 5 \%, 6 \% и 7 \% в течение 12, 18 месяцев в указанных 
модельных условиях при $37^{\circ} \mathrm{C}$. Для исследуемых образцов семян определялись лабораторная всхожесть, длина проростков и содержание абсцизовой кислоты (АБК) в семена для отдельных вариантов опыта.

Обсуждение результатов. Анализ мониторинга всхожести семян ржи через 12, 24 и 36 месяцев хранения свидетельствует о важности хранения семян при влажности не выше 7 \%, достигнутой при соответствующих режимах сушки, причем для хранения при нерегулируемых условиях температуры восточной лесостепи Украины желательна влажность 5-6 \%. При этих уровнях влажности семян после трех лет хранения не установлено преимуществ низких температур хранения над нерегулируемой. Лучший физиологическое состояние проростков семян ржи после двух лет хранения наблюдался при влажности семян $5 \%$ и температуре хранения $-20{ }^{\circ} \mathrm{C}$.

Выводы. По результатам примененного режима ускоренного старения семян, установлено, лучше проводить прогнозирование долговечности семян при влажности семян 7 \%. Анализ содержания АБК в семенах, что хранились при нерегулируемой температуре в условиях восточной лесостепи Украины, $4^{\circ} \mathrm{C}$ и $-20^{\circ} \mathrm{C}$ свидетельствует, что более низкое содержание в семенах АБК наблюдали при более низкой температуре хранения, но по содержанию АБК не удалось спрогнозировать долговечность семян.

Ключевые слова: семена ржи, хранение, содержание влаги, долговечность, абсиизовая кислота

\section{EFFECTS OF DIFFERENT STORAGE REGIMENS ON THE RYE SEED GERMINATION AND ABSCISIC ACID CONTENT}

Zadorozhna $^{1}$ O.A., Yehorov ${ }^{1}$ D.K., Zhmurko $^{2}$ V.V.

${ }^{1}$ Plant Production Institute n.a. V.Ya.Yuriev, Ukraine

${ }^{2}$ V.N.Kararzin National University, Kharkiv, Ukraine

Rye (Secale cereale L.) seed often causes certain difficulties during long-term storage. Earlier common recommendations for modes of rye seed storage were specified.

Purpose and objective. Seed longevity of rye accessions with $5-7 \%$ seed moisture content during storage at unregulated temperature under eastern Forest-Steppe of Ukraine conditions, $4{ }^{\circ} \mathrm{C}$ and $-20{ }^{\circ} \mathrm{C}$ and in the experiment modeling "accelerated aging" conditions was studied.

Material and methods. "Accelerated aging" was carried out by keeping of Kharkivianka variety seeds with a moisture content of $5 \%, 6 \%$ and $7 \%$ for 12,18 months under these model conditions at $37{ }^{\circ} \mathrm{C}$. For the studied seed samples were evaluated laboratory germination, seedling length and abscisic acid content in the seeds for individual variants of the experiment.

Results and discussion. Analysis of rye seed germination monitoring after 12, 24 and 36 months of storage shows the importance of seed storage at moisture content not exceeding $7 \%$, achieved under appropriate drying regimes. Moisture content $5-6 \%$ is preferable for seed storage at unregulated temperature conditions of the eastern forest-steppe of Ukraine. The advantages of low storage temperatures over unregulated ones haven't been established at these levels of moisture content after three years of storage. The best physiological condition of rye seed seedlings after two years of storage was observed at $5 \%$ seed moisture and $-20{ }^{\circ} \mathrm{C}$ storage temperature.

Conclusions. According to the results of the used mode of accelerated aging it is established that it is better to predict seed longevity at a moisture content of 7\%. Analysis of ABA content in seeds stored at unregulated temperature in the eastern forest-steppe of Ukraine, $4{ }^{\circ} \mathrm{C}$ and $20{ }^{\circ} \mathrm{C}$ shows that the lower ABA seed content was at lower storage temperature, but the ABA content didn't predict seed longevity.

Key words: rye seeds; storage; water content; longevity; abscisic acid 